\title{
Lung Cancer cM1 TNM Finding v7
}

National Cancer Institute

\section{Source}

National Cancer Institute. Lung Cancer CM1 TNM Finding v7. NCI Thesaurus. Code C88885.

Lung cancer with distant metastasis. (from AJCC 7th Ed.) 